\title{
Unusual presentation of right coronary artery fistula
}

\author{
Ahmed MSEK Abdelaty, ${ }^{1,2}$ Anvesha Singh, ${ }^{1}$ Gerry P McCann ${ }^{1}$
}

${ }^{1}$ University Hospitals of Leicester NHS Trust, Leicester, UK

${ }^{2}$ Suez Canal University, Ismailia, Egypt

\section{Correspondence to} Dr Ahmed MSEK Abdelaty, amsek1@le.ac.uk

Accepted 19 April 2017

\section{DESCRIPTION}

A female aged 70 years, with no previous comorbidities, was referred with suspected heart failure due to mild exertional dyspnoea, mildly elevated brain-natriuretic peptide (BNP) (139 ng/L) and inferolateral T-inversion on ECG. A transthoracic echocardiogram (TTE) showed a moderate global pericardial effusion, mild left ventricular hypertrophy (LVH), moderate aortic stenosis (AS) and preserved systolic function. Serial TTE's showed a resolving pericardial effusion, moderate left ventricular hypertrophy $(\mathrm{LVH})$ and bi-atrial dilatation, following which cardiac magnetic resonance imaging (CMR) was requested to exclude infiltrative cardiomyopathy. An angiogram was also requested due to suspicion of moderate-to-severe AS, as a work-up for future valve replacement. CMR showed a severely dilated and tortuous right coronary artery (RCA) on Half-Fourier-Acquired Single-shot Turbo spin Echo (HASTE) planning images, draining into an enlarged coronary sinus (figure $1 \mathrm{~A}, \mathrm{~B}$ ). There was moderate lateral wall hypertrophy on cine images (figure 1C,D), with corresponding oedema (increased native T1 value on T1 mapping, with enhancement on early and late gadolinium imaging). The RCA to coronary sinus fistula was also confirmed on the coronary angiogram (figure $1 \mathrm{E}, \mathrm{F}$ and Video 1 ). The lateral wall hypertrophy/oedema was thought to be a direct consequence of the reduced to venous drainage from the lateral wall due to high pressures in the coronary sinus.

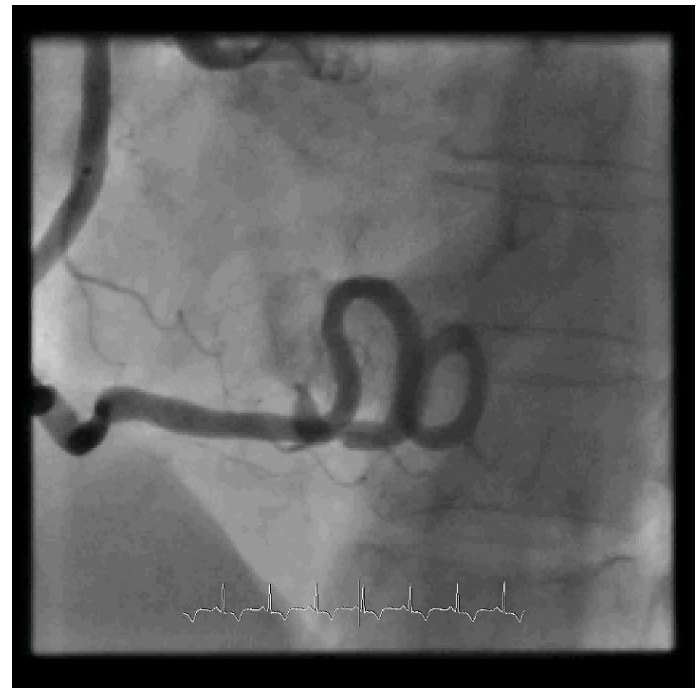

Video 1 Coronary angiography showing a dilated right coronary artery draining into coronary sinus.

Coronary artery fistulas are uncommon, often incidental findings on angiography or autopsy, accounting for $0.15 \%$ of CT coronary angiography, $0.1 \%$ of cardiac catheterisation ${ }^{2}$ and $0.002 \%$ of the general population. ${ }^{3}$ The most common site is the RCA (55\%), followed by the left anterior descending artery. ${ }^{4}$ They often drain into low-pressure structures such as pulmonary artery, coronary sinus, superior vena cava and right heart chambers. ${ }^{4}$ Clinical presentation is usually in the third decade, with

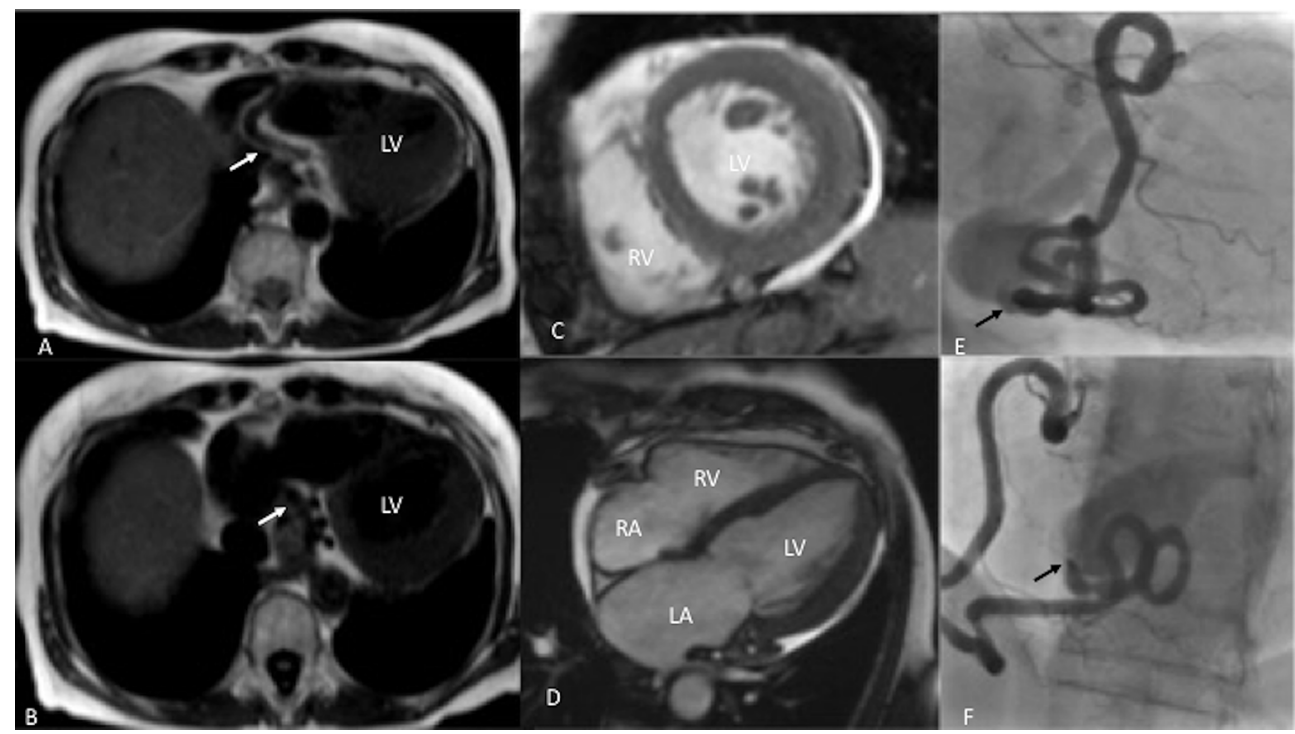

Figure 1 (A,B) HASTE images from cardiac MRI showing dilated coronary sinus (arrows), (C,D) short-axis cine images showing hypertrophied lateral myocardial wall, $(\mathbf{E}, \mathbf{F})$ coronary angiography images showing dilated right coronary artery draining into coronary sinus. 
symptoms of dyspnoea and angina. ${ }^{3}$ Complications rarely include infective endocarditis, myocardial infarction or rupture. Surgical closure is performed for symptoms or complications. Similar cases have previously been diagnosed on TTE and coronary angiography, with CMR used to confirm diagnosis later. ${ }^{36-8}$ The unique features of this case include the presentation with unexplained pericardial effusion, the diagnosis being made by CMR as well as lateral wall thickening secondary to oedema, thought to be due to reduced venous drainage as a direct consequence of the arteriovenous fistula, leading to increased pressure in the coronary sinus.

\section{Learning points}

- Significance of cardiac MRI (CMR) in diagnosing rare condition such as right coronary sinus fistula.

- HASTE images in CMR scan are often overlooked, but in this case the plan of management was completely changed based on these images.

- Right coronary sinus fistula should be in the differential diagnosis of recurrent unexplained pericardial effusion.

Contributors AMSEKA and AS wrote the case report. GPM supervised the scan and made the diagnosis. All authors approved the final manuscript.

Competing interests None declared.

Patient consent Obtained.
Provenance and peer review Not commissioned; externally peer reviewed.

(c) BMJ Publishing Group Ltd (unless otherwise stated in the text of the article) 2017. All rights reserved. No commercial use is permitted unless otherwise expressly granted.

\section{REFERENCES}

1 Graidis C, Dimitriadis D, Karasavvidis V, et al. Prevalence and characteristics of coronary artery anomalies in an adult population undergoing multidetector-row computed tomography for the evaluation of coronary artery disease. BMC CardiovasC Disord 2015;15:112

2 Vavuranakis M, Bush CA, Boudoulas H. Coronary artery fistulas in adults: incidence, angiographic characteristics, natural history. Cathet Cardiovasc Diagn 1995;35:116-20.

3 Androulakis A, Chrysohoou C, Barbetseas J, et al. Arteriovenous connection between the aorta and the coronary sinus through a giant fistulous right coronary artery. Hellenic J Cardio/ 2008;49:48-51.

4 Tiritilli A, laria P, Viard P, et al. Les fistules coronaires, un problème d'actualité : approche clinique et considérations thérapeutiques. Ann Cardiol Angeiol 2016;65:31-7.

5 García-Rinaldi R, Von Koch L, Howell JF. Successful repair of a right coronary arterycoronary sinus fistula with associated left coronary arteriosclerosis. Bol Asoc Med $P R$ 1977;69:156-9.

6 Connections AS. Coronary Arteriovenous Fistulae. 2012;39:1-5.

7 Galaska R, Siondalski P, Kulawiak-Galaska D, et al. Giant right coronary artery fistula to the coronary sinus: multimodal imaging. Eur Heart J Cardiovasc Imaging 2015; $16: 1175$.

8 Komoda S, Komoda T, Ivanitskaia-Kuehn E, et al. Giant aneurysm of the right coronary artery and fistula to the coronary sinus. Gen Thorac Cardiovasc Surg 2010;58:78-81.

Copyright 2017 BMJ Publishing Group. All rights reserved. For permission to reuse any of this content visit

http://group.bmj.com/group/rights-licensing/permissions.

BMJ Case Report Fellows may re-use this article for personal use and teaching without any further permission.

Become a Fellow of BMJ Case Reports today and you can:

- Submit as many cases as you like

- Enjoy fast sympathetic peer review and rapid publication of accepted articles

- Access all the published articles

Re-use any of the published material for personal use and teaching without further permission

For information on Institutional Fellowships contact consortiasales@bmjgroup.com

Visit casereports.bmj.com for more articles like this and to become a Fellow 